\title{
PEMETAAN RENCANA POLA RUANG TERBUKA HIJAU MENGGUNAKAN AHP DAN GIS UNTUK KOTA SUBULUSALAM
}

\author{
Skar Fharaby, Ahmad Perwira Mulia, Anthoni Veery Mardianta
}

Universitas Sumatera Utara, Indonesia

Email: alfharaby.pu@gmail.com,a.perwira.mulia@gmail.com, avmardianta@gmail.com

\begin{tabular}{l}
\hline INFO ARTIKEL \\
\hline Diterima \\
25 Desember 2021 \\
Direvisi \\
10 Januari 2022 \\
Disetujui \\
15 Januari 2022 \\
\hline
\end{tabular}

Kata Kunci: ruang terbuka hijau; analitycal hierarchy process; geographic information system

\section{ABSTRAK}

Undang - undang no 26 tahun 2007 tentang penataan ruang secara tegas mengamanatkan $30 \%$ dari wilayah kota berwujud ruang terbuka hijau, $20 \%$ bersifat publik dan $10 \%$ bersifat privat. Pengalokasian ruang terbuka hijau ini ditetapkan dalam Peraturan Daerah tentang Rencana Tata Ruang Wilayah (RTRW) Daerah yaitu Pemerintah Kota Subulussalam. Pemerintah Kota Subulussalam perlu secepatnya menempatkan masalah ruang terbuka hijau sebagai salah satu isu penting dalam pembahasan program pembangunan berkelanjutan. Tujuan dari penelitian ini adalah memberi tambahan literasi melalui perspektif yang berbeda dari sisi akademis terhadap kawasan lindung yang telah di tetapkan dalam RTRW Kota Subulussalam sebagai perwujudan pola ruang terbuka hijau yang sistematis dan realistis. Metode yang digunakan dalam penelitian ini adalah kuantitatif deskriptif. Dalam hal ini metode integrasi Analitycal Hierarchy Process (AHP) digunakan agar dapat mengambil keputusan yang rasional dari beberapa kriteria tersebut dan Geographic Information System (GIS) sebagai pendukung keputusan dalam penentuan lokasi serta menggambarkannya pada sebuah peta zonasi. Berdasarkan hasil penelitian didapatkan bahwa dari 5 kecamatan di Kota Subulussalam, Kecamatan simpang kiri merupakan kecamatan yang memiliki kebutuhan ruang terbuka hijau paling tinggi. Hal itu dikarenakan $91,86 \%$ wilayah kecamatan simpang kiri memiliki kategori tingkat kebutuhan ruang terbuka hijau sedang hingga sangat tinggi yang berlokasi di area lapangan beringin.

\section{ABSTRACT}

Law No. 26 of 2007 concerning spatial planning explicitly mandates that $30 \%$ of the city area is in the form of green open space, $20 \%$ is public and $10 \%$ is private. The allocation of this green open space is stipulated in the Regional Regulation on Regional Spatial Planning (RTRW), namely the Subulussalam City Government. The Subulussalam City Government needs to immediately place the issue of green open space as one of the

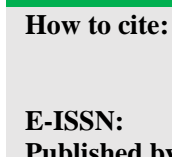

Published by:
Fharaby, S,. Ahmad Perwira Mulia, Anthoni Veery Mardianta (2022) Pemetaan Rencana Pola Ruang Terbuka Hijau Menggunakan AHP dan Gis untuk Kota Subulusalam, Jurnal Syntax Admiration 3(1). https://doi.org/10.46799/jsa.v3i1.374 2722-5356

Ridwan Institute 


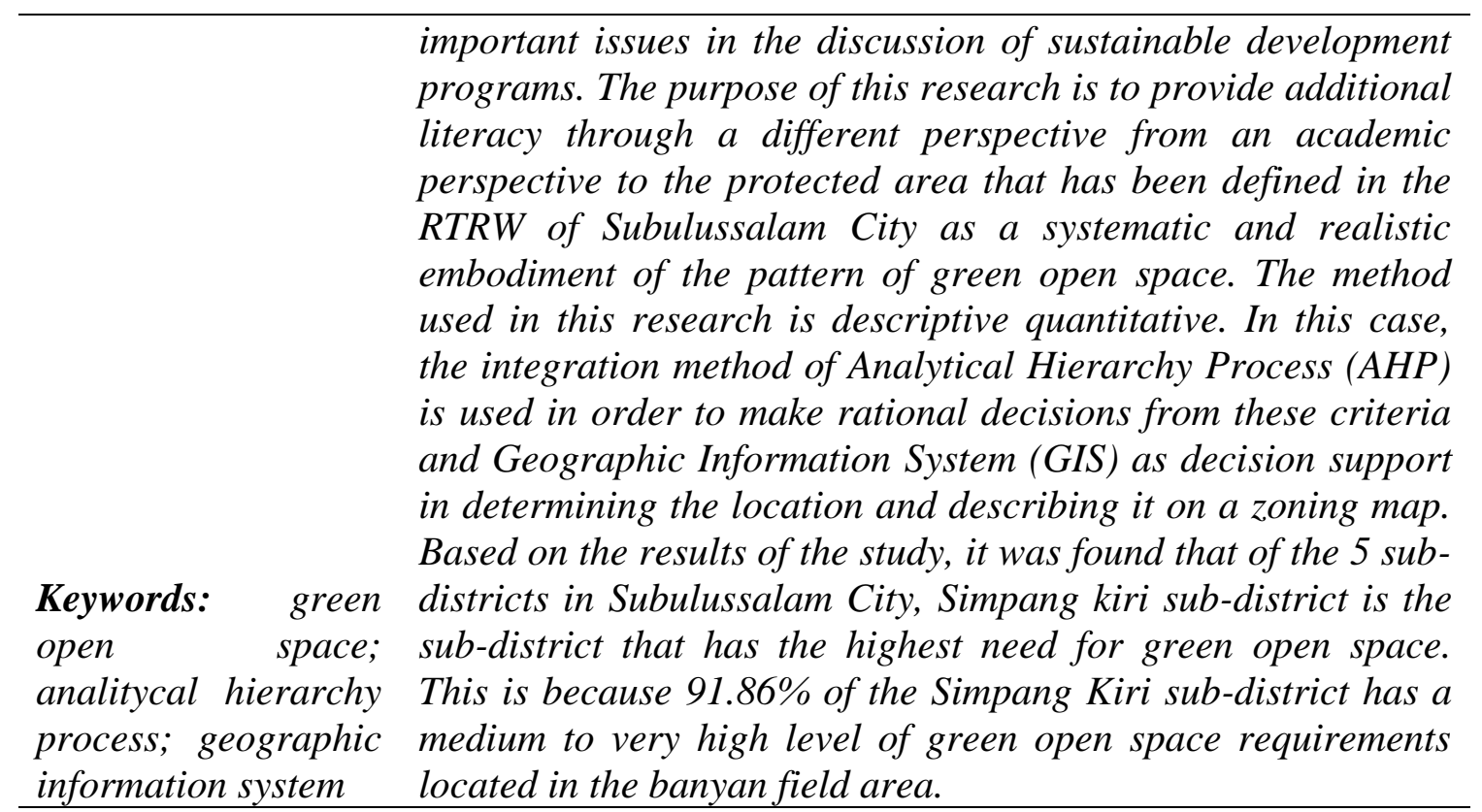

\section{Pendahuluan}

Kota hijau merupakan kota yang ramah lingkungan dengan memanfaatkan secara efektif dan efisien sumber daya air dan energi, mengurangi limbah, menerapkan sistem transportasi terpadu, menjamin kesehatan lingkungan, mensinergikan lingkungan alami dan buatan, yang berpihak pada prinsip-prinsip pembangunan berkelanjutan. Kota hijau yang berkelanjutan merupakan kota yang dibangun dengan terus menerus memupuk semua asset kota, meliputi sumberdaya alam, lingkungan dan kualitas prasarana perkotaan (Manlun, 2003).

Secara fisik ruang terbuka hijau dapat dibedakan menjadi ruang terbuka hijau alami yang berupa habitat liar alami, kawasan lindung dan taman-taman nasional, maupun ruang terbuka hijau non-alami atau binaan seperti taman, lapangan olah raga, dan kebun bunga (Ruang, 2008). Multi fungsi penting ruang terbuka hijau ini sangat lebar spektrumnya, yaitu dari aspek fungsi ekologis, sosial/budaya, arsitektural dan ekonomi (Alifia, N., Purnomo, 2016). Secara arsitektural ruang terbuka hijau dapat meningkatkan nilai keindahan dan kenyamanan kota melalui keberadaan taman-taman kota, kebun-kebun bunga, dan jalur-jalur hijau di jalan-jalan kota (Pokhrel, 2019). (Hendriani, 2016) dalam rangkumannya mengemukakan ruang terbuka hijau juga dapat memiliki fungsi ekonomi, baik secara langsung seperti pengusahaan lahan-lahan kosong menjadi lahan pertanian/perkebunan (urban agriculture) dan pengembangan sarana wisata hijau perkotaan yang dapat mendatangkan wisatawan.

Undang-undang no 26 tahun 2007 tentang penataan ruang secara tegas mengamanatkan $30 \%$ dari wilayah kota berwujud ruang terbuka hijau, $20 \%$ bersifat publik dan $10 \%$ bersifat privat. Pengalokasian ruang terbuka hijau ini ditetapkan dalam peraturan daerah tentang Rencana Tata Ruang Wilayah (RTRW) Kota Subulussalam. Meski struktur pola ruang terbuka hijau ini telah disusun dalam RTRW dan telah di tetapkan dalam peraturan daerah, akan tetapi dewasa ini Pemerintah Kota 
Subulussalam belum mampu memproyeksikan ruang terbuka publik (open spaces) di perkotaan terdiri dari ruang terbuka hijau dan ruang terbuka non-hijau dengan bagian ruang-ruang terbuka (open spaces) suatu wilayah perkotaan yang diisi oleh tumbuhan, tanaman dan vegetasi (endemik maupun introduksi) guna mendukung manfaat ekologis, sosial-budaya dan arsitektural yang dapat memberikan manfaat ekonomi (kesejahteraan) bagi masyarakatnya.

Terkait dengan hal tersebut, penyusunan penelitian ini diharapkan mampu memberi tambahan literasi terkait penyusunan pola ruang terbuka hijau yang telah tersusun dalam Rencana Tata Ruang Wilayah (RTRW) Kota Subulussalam dengan menggunakan metode pengambilan keputusan yaitu Analitycal Hierarchy Process (AHP) berdasarkan beberapa kriteria yang akan di sajikan dalam penelitian ini serta memetakan eksisting dan hasil secara teknis menggunakan salah satu software dari Geographic Information System (GIS).

AHP merupakan sistem pembuat keputusan dengan menggunakan model matematis. Analisisnya membantu dalam menentukan prioritas dari beberapa kriteria dengan melakukan analisa perbandingan berpasangan dari masing-masing kriteria.

GIS adalah sebuah sistem informasi khusus yang mengelola data yang memiliki informasi spasial (bereferensi keruangan). Setiap data yang menunjukan tentang suatu lokasi di permukaan bumi dapat disebut sebagai data spasial bereferensi keruangan/ geografis. Output yang dihasilkan dari sistem ini adalah sebuah peta wilayah yang berisi informasi yang bersifat spasial (Saputra, 2019).

Kriteria-kriteria AHP dan GIS dalam penelitian ini ditentukan dari studi literatur, jurnal-jurnal ilmiah serta juga berdasarkan hasil diskusi dengan para ahli yang berkompeten di bidangnya (Manlun, 2003). menganalisa kesesuaian sistem perancangan ruang terbuka hijau menggunakan kriteria kualitas udara, kualitas landscape, kualitas air permukaan kualitas air permukaan, nilai budaya bersejarah, pengaruh sistem air, pengaruh kebisingan dan penggunaan lahan yang ada. (Li, et al, 2018) dalam analisisnya menggunakan AHP dengan kriteria-kriteria aktivitas manusia, bentang alam alami, situs sejarah, penggunaan lahan yang ada, sumber polusi infrastruktur penting, lalu lintas jalan, pohon kuno dan langka, wilayah perairan, kemiringan (slope), ketinggian bencana geologi (geological disasters), dan kawasan zona ekologi. (Abebe \& Megento, 2017) menentukan sumber daya yang cocok untuk beberapa spesies tertentu dalam perencanaan ruang hijau kota di kota Addis Ababa menggunakan AHP dengan kriteria kepadatan penduduk, jarak dari jalan raya, jarak dari sungai, dari tempat bersejarah, kebisingan, jarak pengaruh dari taman eksisting, kemiringan lereng, jenis tanah (soil type).

Tujuan dari penelitian ini adalah mengidentifikasi kawasan ruang terbuka hijau didalam pola ruang kota yang telah di susun dan ditetapkan dalam peraturan daerah Kota Subulussalam tentang RTRW dan menganalisa kawasan ruang terbuka hijau didalam pola ruang kota tersebut dalam pemenuhan kriteria yang akan disepakati melalui metode AHP dan GIS. 
Penelitian serupa juga telah dilakukan terkait perancangan ruang terbuka hijau dengan metode AHP dan GIS. Beberapa peneliti seperti (Ostad-Ali-Askari et al., 2018) melakukan penelitian terkait identifikasi tumpang tindihnya area terbuka hijau di provinsi Isfahan, Iran. Selain itu, (Hamdaningsih, S. S., Fandeli, C., Baiquni, 2010) juga menganalisis kebutuhan hutan kota di Kota Mataram untuk menjaga kualitas lingkungan sekarang dan lima tahun mendatang, dan menganalisis besarnya kemampuan berbagai jenis vegetasi hutan kota dalam mengurangi akumulasi karbon di udara serta menyajikan sebaran hutan kota yang dibutuhkan yang disesuaikan dengan konsep tata ruang. M'Ikiugu et,al (2012) menganalisa dan mengidentifikasi ruang hijau perkotaan dan mengidentifikasi zona kawasan perluasannya menggunakan menggunakan metode AHP. Aji, et al (2015) dan Agus et, al (2017) juga melakukan analisis menggunakan metode AHP.

\section{Metode Penelitian}

Penelitian ini merupakan jenis penelitian kuantitatif deskriptif. Penelitian ini dilakukan dalam satu wilayah dan waktu tertentu, guna mendapatkan gambaran menyeluruh tentang daerah situasi pemanfaatan ruang terbuka hijau yaitu wilayah Kota Subulussalam.

Kriteria yang signifikan pada umumnya digunakan untuk mengembangkan kerangka metode AHP untuk mengidentifikasi lokasi terbaik. Dalam penelitian ini digunakan kriteria yaitu point of interest, slope, land use, akses jalan, demografi dan jenis tanah, untuk pemetaan rencana pola ruang terbuka hijau di Kota Subulussalam Aceh. Selanjutnya metode AHP diterapkan untuk pembobotan dan pemeringkatan berdasarkan pentingnya RTH tersebut.

Secara garis besar, tahapan dalam penelitian ini digambarkan dalam bagan alir seperti terlihat pada gambar di bawah ini. 


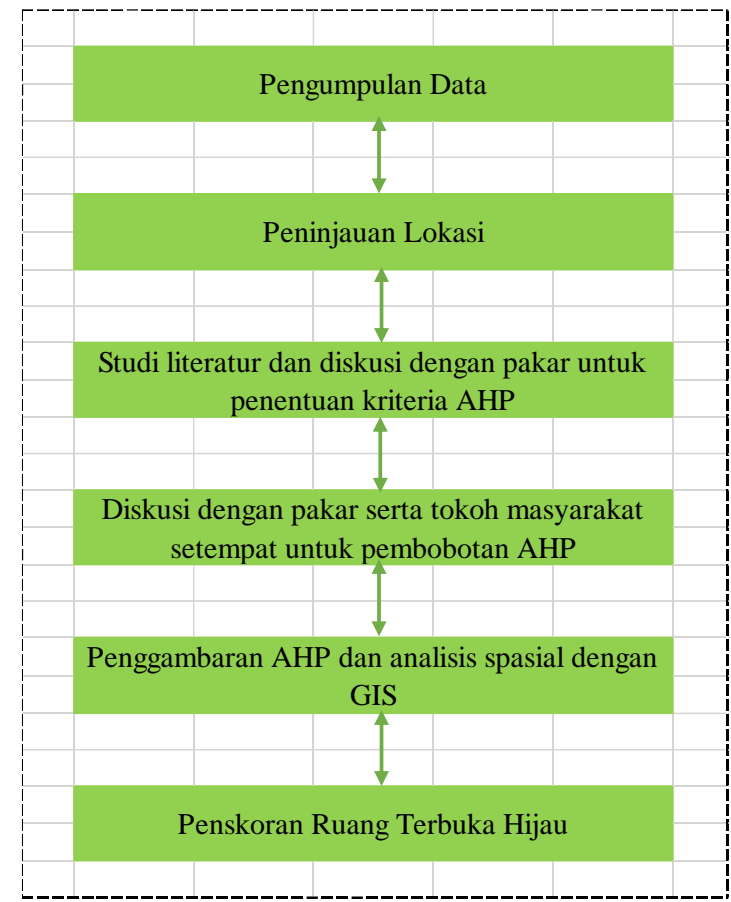

Gambar 1

Bagan Alir Penelitian

\section{Hasil dan Pembahasan}

\section{Identifikasi dan Penilaian Bobot Tiap Kriteria}

Kriteria dalam AHP untuk penentuan rencana pola ruang terbuka hijau di Kota Subulussalam ditentukan dengan metode expert judgement atau dengan disepakati oleh para ahli yang berkompeten di bidangnya serta dengan mempelajari literaturliteratur dan jurnal-jurnal ilmiah yang terkait dengan penelitian ini. Kriteria yang digunakan dalam penelitian ini adalah Point of Interest (POI), kemiringan (Slope), tata guna lahan (Land use), jalan (Roads), demografi (demographical data) dan jenis tanah (geologi).

Tahapan selanjutnya adalah penilaian bobot antar kriteria tersebut dilakukan dengan Focus group discussion yang melibatkan para pihak antara lain Expert atau para ahli dari Universitas Sumatera Utara yang berkompeten dalam melakukan analisa pengambilan keputusan, Pemerintahan sebagai pemangku kebijakan dan para Tokoh masyarakat setempat sebagai perwakilan pihak yang terdampak pada pemanfaatan RTH tersebut.

Hasil dari penilaian menggunakan kuesioner tersebut disepakati seperti yang terlihat pada gambar Gambar 2. 
Pemetaan Rencana Pola Ruang Terbuka Hijau Menggunakan Ahp dan Gis Untuk Kota Subulusalam

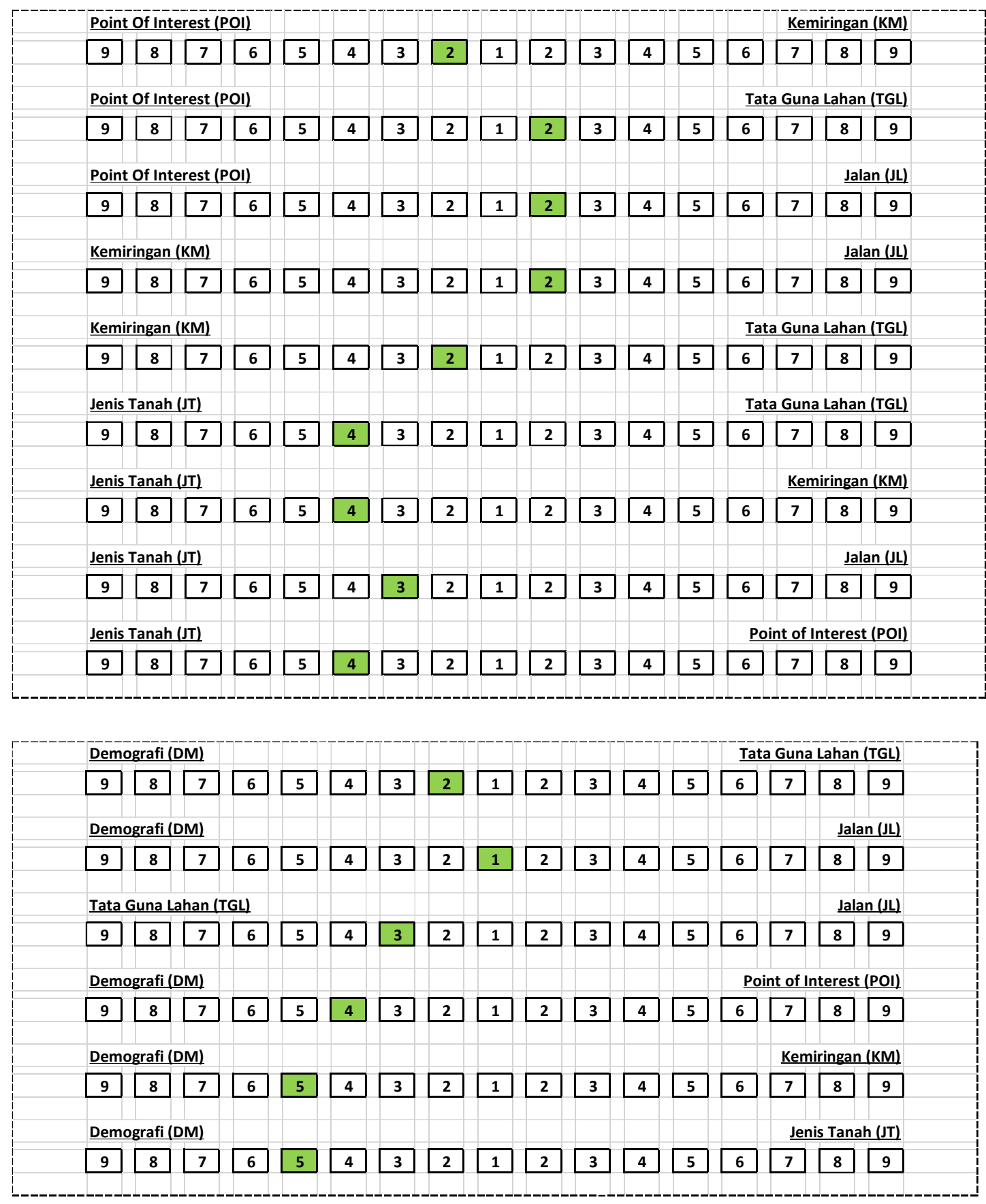

Gambar 1

Hasil penilaian kuisioner bobot antar kriteria

Seluruh hasil penilaian yang didapat dari kuisioner tersebut akan direkapitulasi ke dalam Tabel 1. 
Tabel 1

Identifikasi Perbandingan Antar Kriteria

\begin{tabular}{lllllll}
\hline & POI & KM & TGL & JL & DM & JT \\
\hline POI & 1,00 & 2,00 & $1 / 2$ & $1 / 2$ & $1 / 4$ & $1 / 4$ \\
\hline KM & $1 / 2$ & 1,00 & 2,00 & $1 / 2$ & $1 / 5$ & $1 / 4$ \\
\hline TGL & 2,00 & $1 / 2$ & 1,00 & 3,00 & $1 / 2$ & $1 / 4$ \\
\hline JL & 2,00 & 2,00 & $1 / 3$ & 1,00 & 1,00 & $1 / 3$ \\
\hline DM & 4,00 & 5,00 & 2,00 & 1,00 & 1,00 & 5,00 \\
\hline JT & 4,00 & 4,00 & 4,00 & 3,00 & $1 / 5$ & 1,00 \\
\hline
\end{tabular}

Sumber: Hasil Analisis

\section{Perhitungan Bobot Tiap Kriteria}

Perhitungan nilai bobot tiap kriteria dilakukan dengan merubah nilai pada tabel identifikasi antar kriteria di atas harus ke nilai desimal agar dapat diketahui jumlahnya, seperti ditunjukkan pada Tabel 2.

Tabel 2

Nilai Desimal Identifikasi Perbandingan Antar Kriteria

\begin{tabular}{lllllll}
\hline & POI & KM & TGL & JL & DM & JT \\
\hline POI & 1,00 & 2,00 & 0,50 & 0,50 & 0,25 & 0,25 \\
\hline KM & 0,50 & 1,00 & 2,00 & 0,50 & 0,20 & 0,25 \\
\hline TGL & 2,00 & 0,50 & 1,00 & 3,00 & 0,50 & 0,25 \\
\hline JL & 2,00 & 2,00 & 0,33 & 1,00 & 1,00 & 0,33 \\
\hline DM & 4,00 & 5,00 & 2,00 & 1,00 & 1,00 & 5,00 \\
\hline JT & 4,00 & 4,00 & 4,00 & 3,00 & 0,20 & 1,00 \\
\hline Jumlah & 13,50 & 14,50 & 9,83 & 9,00 & 3,15 & 7,08 \\
\hline
\end{tabular}

Sumber: Hasil Analisis

Tahapan selanjutnya adalah melakukan penghitungan sintesis pada setiap nilai yang tercantum pada tabel di atas Proses penghitungan akan dibagi per masingmasing kolom. Berdasarkan hasil perhitungan yang telah dilakukan, selanjutnya nilai yang dihasilkan direkapitulasi ke dalam Tabel 3 dan dijumlahkan untuk nilai priority vector.

Tabel 3

Rekapitulasi Perhitungan

\begin{tabular}{cccccccc}
\hline & POI & KM & TGL & JL & DM & JT & $\begin{array}{c}\text { Priority } \\
\text { Vector }\end{array}$ \\
\hline POI & 0,07 & 0,13 & 0,05 & 0,05 & 0,07 & 0,03 & 0,400 \\
\hline KM & 0,03 & 0,06 & 0,20 & 0,05 & 0,06 & 0,03 & 0,430 \\
\hline TGL & 0,14 & 0,03 & 0,10 & 0,33 & 0,15 & 0,03 & 0,830 \\
\hline JL & 0,14 & 0,13 & 0,03 & 0,11 & 0,31 & 0,04 & 0,763 \\
\hline DM & 0,29 & 0,34 & 0,20 & 0,11 & 0,31 & 0,70 & 1,950 \\
\hline JT & 0,29 & 0,27 & 0,40 & 0,33 & 0,06 & 0,14 & 1,490 \\
\hline
\end{tabular}

Sumber: Hasil Analisis

Tahap akhir proses penghitungan nilai atau bobot tiap kriteria adalah dengan men-sintesis-kan atau membagi nilai priority vector tiap kriteria dengan nilai jumlah keseluruhannya, seperti ditunjukkan pada perhitungan di bawah ini: 
1. Point of Interest $(\mathrm{POI})=\frac{0,400}{6,000}=0,066$

2. Slope / Kemiringan $(\mathrm{KM})=\frac{0,430}{6,000}=0,071$

3. Land Use / Tata Guna Lahan (TGL) $=\frac{0,830}{6,000}=0,138$

4. Roads / Jalan $(\mathrm{JL})=\frac{0,763}{6,000}=0,127$

5. Demographical Data / Demografi $(\mathrm{DM})=\frac{1,950}{6,000}=0,325$

6. Jenis Tanah $(\mathrm{JT})=\frac{1,490}{6,000}=0,248$

\section{Pengujian Konsistensi Hasil AHP}

Pengujian konsistensi hasil AHP ini terdiri dari beberapa tahapan, yaitu:

1. Penghitungan nilai $\lambda$ max dengan cara perkalian matriks antara bobot dengan nilai identifikasi masing-masing kriteria.

$$
\begin{aligned}
& 0,066\left[\begin{array}{c}
1 \\
1 / 2 \\
2 \\
2 \\
4 \\
4
\end{array}\right]+0,071\left[\begin{array}{c}
2 \\
1 \\
1 / 2 \\
2 \\
5 \\
4
\end{array}\right]+0,138\left[\begin{array}{c}
1 / 2 \\
2 \\
1 \\
1 / 3 \\
2 \\
4
\end{array}\right]+0,248\left[\begin{array}{c}
1 / 4 \\
1 / 4 \\
1 / 4 \\
1 / 3 \\
5 \\
1
\end{array}\right]=\left[\begin{array}{l}
0,484 \\
0,571 \\
0,911 \\
0,855 \\
2,587 \\
1,794
\end{array}\right] \\
& 0,127\left[\begin{array}{c}
1 / 5 \\
1 / 2 \\
1 / 2 \\
1 \\
1 \\
3
\end{array}\right]+0,325\left[\begin{array}{c}
1 \\
1 / 5
\end{array}\right]
\end{aligned}
$$

2. Hasil perkalian matriks tiap kriteria dibagi lagi dengan bobot dari kriteria tersebut

$$
\begin{array}{lll}
\frac{0,484}{0,066}=6,330 & \frac{0,571}{0,071}=6,035 & \frac{0,911}{0,138}=6,601 \\
\frac{0,855}{0,127}=6,730 & \frac{2,587}{0,325}=6,960 & \frac{1,794}{0,248}=6,234
\end{array}
$$

3. Nilai pembagian yang didapat, dijumlahkan keseluruhan dan dibagi rata-rata: 
Skar Fharaby, Ahmad Perwira Mulia, Anthoni Veery Mardianta

$$
\begin{aligned}
& \lambda_{\max }=\frac{6,330+6,035+6,601+6,730+6,960+6,234}{6} \\
& \lambda_{\max }=6,48
\end{aligned}
$$

4. Setelah diketahui nilai $\lambda \max$, maka tahapan selanjutnya adalah mendapatkan nilai concistency index $(\mathrm{CI})$ :

$$
\mathrm{CI}=\frac{\lambda_{\max -n}}{n-1}=\frac{6,48-6}{6-1}=0,09
$$

5. Dengan melihat dari tabel konsistensi acak / random consistency (RI) (Tabel 3,9), maka diketahui nilai RI adalah 1,24 untuk $n=6$.

6. Tahapan akhir untuk mengetahui nilai consistency ratio $(\mathrm{CR})$ adalah dengan perhitungan:

$$
\mathrm{CR}=\frac{\mathrm{CI}}{\mathrm{RI}}=\frac{0,09}{1,24}=\mathbf{0 , 0 7}<\mathbf{0 , 1}
$$

Syarat hasil perhitungan AHP dapat dinyatakan konsisten dalam menghasilkan keputusan adalah nilai CR harus lebih kecil dari 0,1. Sehingga dapat dikatakan bahwa hasil perhitungan AHP untuk penelitian ini telah memenuhi syarat.

\section{Penggabungan Skor AHP dari Seluruh Kriteria Mengunakan GIS}

Proses ini adalah menyatukan semua nilai (skoring) pada tiap peta kriteria menjadi satu peta menggunakan GIS. Tahapan penggabungan skor AHP dan peta GIS dari seluruh kriteria ini adalah sebagai berikut:

1. Pada setiap peta kriteria yang telah terklasifikasi dibuat pembagian area ( $\mathrm{grid}$ ) dengan dimensi $100 \mathrm{~m}$ x $100 \mathrm{~m}$. Area yang terbentuk sebanyak 119.608 area.

2. Setiap area yang berukuran $100 \mathrm{~m} \times 100 \mathrm{~m}$ tersebut berisi nilai klasifikasi tiap kriteria yang akan dikalikan dengan bobot kriterianya dan dijumlahkan

\begin{tabular}{|c|c|c|c|c|c|c|}
\hline & POI & KM & TGL & $\mathbf{J L}$ & DM & JT \\
\hline Bobot & 0,066 & 0,071 & 0,138 & 0,127 & 0,325 & 0,248 \\
\hline $\begin{array}{ll}\text { Skor } & \text { Klasifikasi } \\
\text { Kriteria } & \end{array}$ & 2 & 3 & 1 & 1 & 3 & 5 \\
\hline Skor Akhir & 0,132 & 0,213 & 0,138 & 0,127 & 0,975 & 1,240 \\
\hline
\end{tabular}
keseluruhan untuk mendapatkan skor gabungan, seperti contoh di bawah ini :

Tabel 4

Skor Gabungan untuk Tiap Kriteria

Sumber: Hasil Analisis

3. Setelah diketahui total skor gabungan, maka nilai tersebut menjadi parameter yang akan dimasukkan dalam peta hasil akhir AHP pada Gambar 3. 
4. Penilaian akhir tersebut akan dibagi dalam 5 klasifikasi, seperti yang ditampilkan pada Tabel 5.

Tabel 5

Klasifikasi Tingkat Kebutuhan

\begin{tabular}{lcl}
\hline Kebutuhan Ruang Terbuka Hijau & Skor & \multicolumn{1}{l}{ Notasi warna } \\
\hline Sangat rendah / very low & $0,00-2,00$ & \multicolumn{1}{c}{ Hijau Tua } \\
\hline Rendah / low & $2,00-3,00$ & Hijau Muda \\
\hline Sedang / moderate & $3,00-3,70$ & Kuning \\
\hline Tinggi / high & $3,70-4,30$ & Jingga \\
\hline Sangat tinggi / very high & $4,30-4,70$ & Merah \\
\hline
\end{tabular}

Sumber: Hasil Analisis

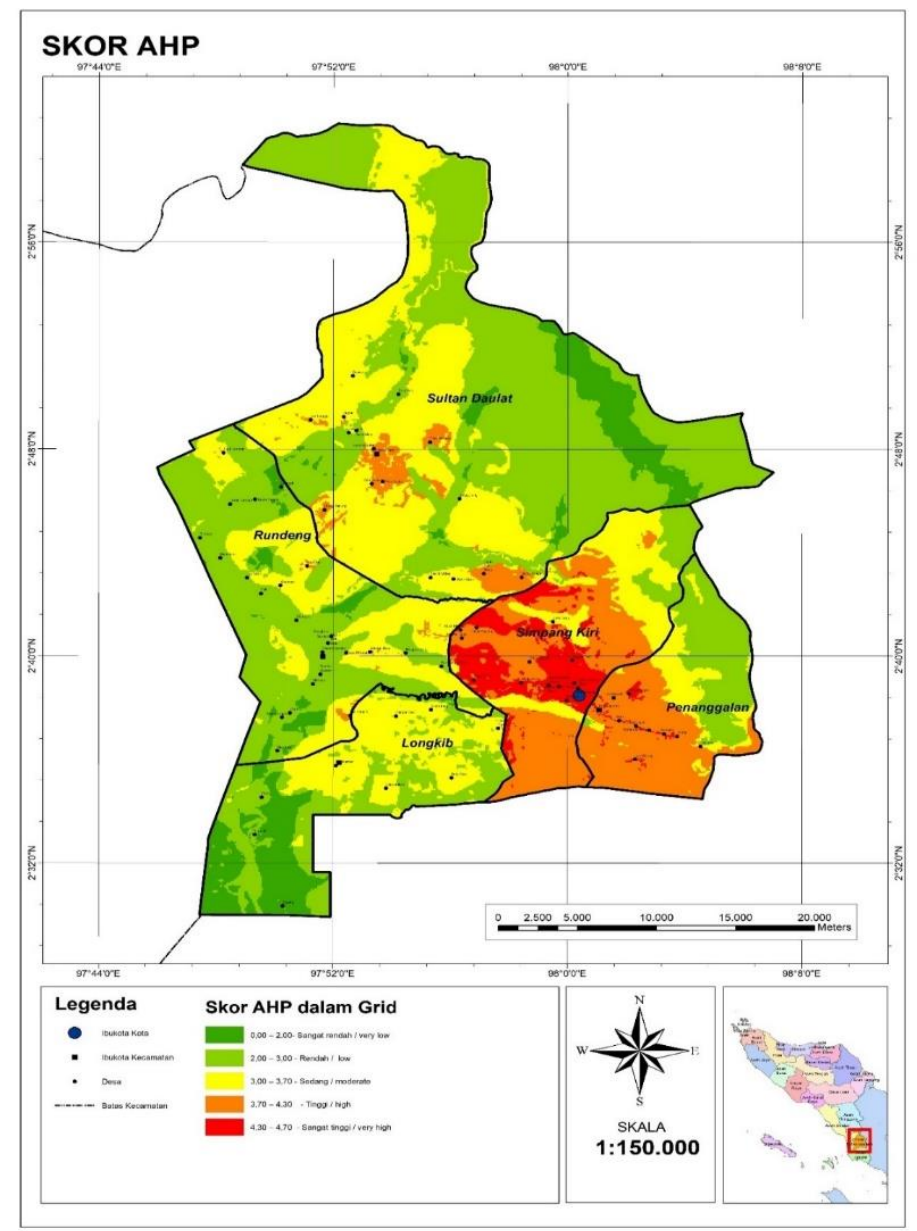

Gambar 2

Peta Analisa AHP dengan Grid 
Hasil dari zonasi ruang terbuka hijau seluruh area pada wilayah Kota Subulussalam, didapatkan hasil sebagai berikut:

1. Area dengan tingkat kebutuhan ruang terbuka hijau sangat rendah seluas $4.027,47$ ha atau setara dengan 3,40\%.

2. Area dengan tingkat kebutuhan ruang terbuka hijau rendah seluas $15.226,11$ ha atau setara dengan $12,86 \%$.

3. Area dengan tingkat kebutuhan ruang terbuka hijau sedang seluas $37.962,10$ ha atau setara dengan 32,06\%.

4. Area dengan tingkat kebutuhan ruang terbuka hijau tinggi seluas $52.315,18$ ha atau setara dengan $44,18 . \%$.

5. Area dengan tingkat kebutuhan ruang terbuka hijau sangat tinggi seluas $8.873,21$ ha atau dengan $7,49 \%$.

Zonasi zonasi ruang terbuka hijau seluruh area pada wilayah Kota Subulussalam ditunjukkan pada Tabel 5.

Tabel 6

Skor AHP Tiap Kecamatan

\begin{tabular}{|c|c|c|c|c|c|c|c|}
\hline \multirow{2}{*}{ No } & \multirow{2}{*}{ Kecamatan } & \multirow{2}{*}{ Keterangan } & \multicolumn{5}{|c|}{ Skor AHP } \\
\hline & & & $0-2$ & $2-3$ & $3-3,7$ & $3,7-4,3$ & $4,3-5,0$ \\
\hline \multirow[b]{3}{*}{1.} & \multirow[b]{3}{*}{ Longkib } & Luas area (ha & $4.032,29$ & $5.966,77$ & $5.803,50$ & 9,19 & 3,04 \\
\hline & & Jumlah Grid & 4.032 & 5.967 & 5.803 & 9 & 3 \\
\hline & & $\begin{array}{c}\% \text { dari luas } \\
\text { kecamatnnya) }\end{array}$ & 25,50 & 37,73 & 36,70 & 0,06 & 0,02 \\
\hline \multirow[b]{3}{*}{2.} & \multirow[b]{3}{*}{ Penanggalan } & Luas area (ha & & $3.918,15$ & $1.803,57$ & $5.668,58$ & 221,90 \\
\hline & & Jumlah Grid & - & 3.918 & 1.804 & 5.669 & 222 \\
\hline & & $\begin{array}{c}\% \text { dari luas } \\
\text { kecamatnnya) }\end{array}$ & - & 33,74 & 15,53 & 48,82 & 1,91 \\
\hline \multirow[b]{3}{*}{3.} & \multirow[b]{3}{*}{ Rundeng } & Luas area (ha & $1.097,54$ & $12.848,50$ & $7.874,21$ & 181,96 & 9,03 \\
\hline & & Jumlah Grid & 1.098 & 12.848 & 7.874 & 182 & 9 \\
\hline & & $\begin{array}{c}\% \text { dari luas } \\
\text { kecamatnnya) }\end{array}$ & 4,99 & 58,37 & 35,77 & 0,83 & 0,04 \\
\hline \multirow[b]{3}{*}{4.} & \multirow{3}{*}{$\begin{array}{l}\text { Simpang } \\
\text { Kiri }\end{array}$} & Luas area (ha & 2,65 & $1.401,84$ & $4.114,68$ & $7.287,84$ & $3.788,99$ \\
\hline & & Jumlah Grid & 3 & 1.402 & 4.115 & 7.288 & 3.789 \\
\hline & & $\begin{array}{c}\% \text { dari luas } \\
\text { kecamatnnya) }\end{array}$ & 0,02 & 8,45 & 24,79 & 43,91 & 22,83 \\
\hline \multirow[b]{3}{*}{5.} & \multirow{3}{*}{$\begin{array}{l}\text { Sultan } \\
\text { daulat }\end{array}$} & Luas area (ha & $3.740,74$ & $28.179,92$ & $18.366,04$ & $2.078,53$ & 4,51 \\
\hline & & Jumlah Grid & 3.741 & 28.180 & 18.366 & 2.079 & 5 \\
\hline & & $\begin{array}{c}\% \text { dari luas } \\
\text { kecamatnnya) }\end{array}$ & 7,14 & 53,81 & 35,07 & 3,97 & 0,01 \\
\hline
\end{tabular}

\section{Kesesuaian Sebaran RTH Terhadap Skoring AHP}

Berdasarkan hasil analisa tingkat kebutuhan ruang terbuka hijau dari masingmasing kecamatan di atas, terlihat bahwa kecamatan simpang kiri sangat mendominasi kebutuhan ruang terbuka hijau tersebut yaitu kebutuhan tinggi (high) 
dengan luas 7.287,84 $\mathrm{Ha}$ atau sekitar 43,91\% dan sangat tinggi (very high) dengan luas $3.788,99 \mathrm{Ha}$ atau sekitar $22,83 \%$ dari luas total kecamatan.

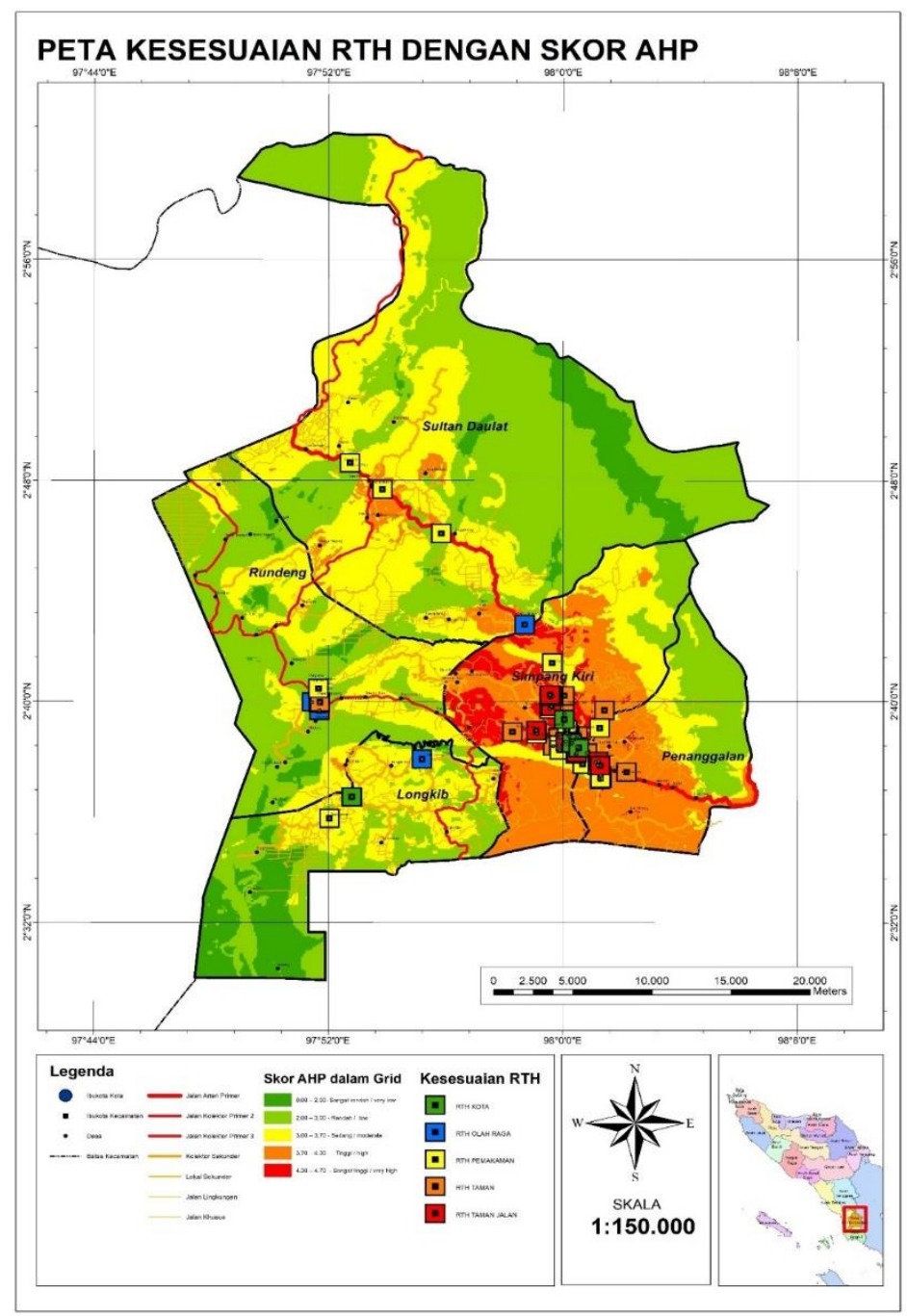

\section{Gambar 4 \\ Peta Analisa AHP dengan Grid \\ Kecamatan Simpang Kiri}

Seperti yang ditunjukkan pada Gambar 4, sebaran lokasi RTH terbanyak terdapat di Kecamatan Simpang Kiri yang merupakan area pusat kota, pemukiman, dan perdagangan. Di dalam area tersebut kepadatan penduduknya cukup tinggi.

Berdasarkan beberapa Sebaran Titik Lokasi RTH yang telah di tetapkan di RTRW Kota Subulussalam terdapat 66 Lokasi RTH terdiri dari RTH Kota, RTH Pemakaman, RTH Olah Raga dan RTH Taman Jalan yang tersebar di seluruh wilayah Kota Subulussalam, dari beberapa lokasi tersebut terdapat kawasan RTH yang tidak sesuai dengan hasil Analisa Skoring AHP, yang artinya terdapat ketidaksesuaian dalam perencanaan dengan kondisi daya dukung lingkungan di 
lapangan, wilayah yang memiliki kriteria tidak sesuai terdapat pada kecamatan Rundeng dan Sultan Daulat.

\section{Kesimpulan}

Berdasarkan hasil dan analisa yang telah dilakukan pada penelitian ini, maka dapat disimpulkan bahwa pemetaan ruang terbuka hijau dapat dilakukan secara rasional dan konsisten berdasarkan AHP dengan mempertimbangkan 2 aspek, yaitu aspek teknis berupa slope/ kemiringan, jalan / road dan jenis tanah / geologi, kemudian juga dengan aspek sosial lingkungan berupa point of interest, land usel tata guna lahan dan demographical data/ data kependudukan.

Saat ini dari hasil analisa tingkat kebutuhan ruang terbuka hijau di area wilayah Kota Subulussalam, didapatkan hasil sebagai berikut: Kebutuhan ruang terbuka hijau sangat rendah 4.027,47 ha (3,40\%.), kebutuhan ruang terbuka hijau rendah 15.226,11 ha $(12,86 \%$.), kebutuhan ruang terbuka hijau sedang $37.962,10$ ha $(32,06 \%$.), kebutuhan ruang terbuka hijau tinggi 52.315,18 ha (44,18\%.), kebutuhan ruang terbuka hijau sangat tinggi 8.873,21 ha (7,49 3,40\%.).

Simpang kiri merupakan kecamatan yang memiliki kebutuhan ruang terbuka hijau paling tinggi dari 5 kecamatan di Kota Subulussalam, Kecamatan. Hal itu dikarenakan 91,86\% wilayah kecamatan simpang kiri memiliki kategori tingkat kebutuhan ruang terbuka hijau sedang hingga sangat tinggi yang berlokasi di area lapangan beringin.

Berdasarkan hasil analisis, dari 66 titik sebaran lokasi RTH di kota Subulussalam terdapat 6 titik atau 2 kecamatan yang tidak sesuai dengan analisa skoring AHP. 


\section{BIBLIOGRAFI}

Abebe, M. T., \& Megento, T. L. (2017). Urban green space development using GISbased multi-criteria analysis in Addis Ababa metropolis. Applied Geomatics, 9(4), 247-261. Google Scholar

Alifia, N., Purnomo, Y. (2016). Identifikasi Letak dan Jenis Ruang Terbuka Hijau di Kawasan Permukiman Perkotaan. Jurnal Arsitektur, 3(2). Google Scholar

Aji, A. S., Suprayogi, A., Wijaya, A. P. (2015). Analisis Kesesuaian Kawasan Peruntukan Pemakaman Umum Baru Berbasis Sistem Informasi Geografis (SIG) (Studi Kasus : Kecamatan Tembalang, Kota Semarang). Jurnal Geodesi Undip Vol. 4, no. 4, pp. 99-107, Nov. 2015. Google Scholar

Agus, F., Azhari, M., Armanda, A., Silalahi, W. (2017). Studi Pendahuluan Perancangan Web SIG Pendukung Keputusan Untuk Penentuan Lokasi Hutan Kota Balikpapan. Jurnal Informatika Mulawarman Vol. 12, No. 2, September 2017. Google Scholar

Hamdaningsih, S. S., Fandeli, C., Baiquni, M. (2010). Studi Kebutuhan Hutan Kota Berdasarkan Kemampuan Vegetasi Dalam Penyerapan Karbon Di Kota Mataram. Majalah Geografi Indonesia. Google Scholar

Hendriani, A. S. (2016). Ruang Terbuka Hijau Sebagai Infrastruktur Hijau Kota pada Ruang Publik Kota (Studi Kasus: Alun-Alun Wonosobo). Jurnal Penelitian Dan Pengabdian Kepada Masyarakat UNSIQ, 3(2). Google Scholar

Manlun, Y. (2003). Suitability Analysis of Urban Green Space System Based on GIS. Google Scholar

M'Ikiugu, M. M., Kinoshita, I., Tashiro, Y. (2012). Urban Green Space Analysis and Identification of its Potential Expansion Areas. SciVerse ScienceDirect. Asia Pacific International Conference on Environment-Behaviour Studies, Salamis Bay Conti Resort Hotel, Famagusta, North Cyprus, 7-9 December 2011. Google Scholar

Ostad-Ali-Askari, K., Dorvashi, M., \& Ghasemi, Z. (2018). Localization of City Park Using AHP in GIS, Case Study: District 8 Area of Isfahan, Isfahan Province, Iran. Arch Ind Biotechnol. 2018; 2 (1): 1-3 2 Arch Ind Biotechnol 2018 Volume 2 Issue, 1. Google Scholar

Pokhrel, S. (2019). Green space suitability evaluation for urban resilience: an analysis of Kathmandu Metropolitan city, Nepal. Environmental Research Communications, 1(10), 105003. Google Scholar

Ruang, D. J. P. (2008). Peraturan Menteri Pekerjaan Umum nomor: 05/PRT/M/2008 tentang Pedoman Penyediaan dan Pemanfaatan Ruang Terbuka Hijau di Kawasan Perkotaan. Jakarta: Departemen Pekerjaan Umum. Google Scholar 
Skar Fharaby, Ahmad Perwira Mulia, Anthoni Veery Mardianta

Saputra, N. A. (2019). Pemetaan Zona Rawan Banjir Rob di Wilayah Medan Utara dengan AHP dan GIS. Tesis Pasca Sarjana Teknik Sipil Universitas Sumatera Utara. Google Scholar

\section{Copyright holder:}

Skar Fharaby, Ahmad Perwira Mulia, Anthoni Veery Mardianta (2022)

First publication right:

Jurnal Syntax Admiration

This article is licensed under:

(c) (i) () 